\title{
ВЕРБАЛИЗАЦИЯ КОНЦЕПТА «БОГАТСТВО И БЕДНОСТЬ» В ПАРЕМИОЛОГИЧЕСКОЙ КАРТИНЕ МИРА
}

\section{VERBALIZATION OF THE CONCEPT OF WEALTH AND POVERTY IN THE PAREMIOLOGICAL PICTURE OF THE WORLD}

\section{N. Gadzhiakhmedov Z. Ziyaudinova}

Summary: The article examined the conceptual and axiological composition of the concepts of "wealth» and "poverty» in the Dargin paremiological picture of the world. Concept «wealth» in the Dargwa language picture of the world lexemes davlachev «the rich man, the rich man» represent, davlachevs «rich», durkhjas «rich», arch «money», and the concept "poverty» is expressed by a lexeme miskin «the poor; poor» with derivatives of miskindesh "poverty», miskinsi «poor». The archiseme of the lexical meaning of the word gave wealth is «the presence of material values», and the archiseme of the lexical meaning of the word miskin «poor» is the absence of these values. The concept of «wealth» and "poverty» has one foundation, but different peaks.

Keywords: the concept of «wealth», the concept of «poverty», the conceptosphere, proverbs and sayings, paremia.
Гаджиахмедов Нурмагомед Эльдерханович

Д.филол.н., профессор, Дагестанский государственный университет (2. Махачкала)

nur1@yandex.ru

Зияудинова Загидат Исмаиловна соискатель, Дагестанский государственный университет (2. Махачкала)

zagidatik@mail.ru

Аннотация: В статье рассматривается понятийная и аксиологическая составляющие концептов «богатство» и «бедность» В даргинской паремиологической картине мира. Концепт «богатство» в даргинской языковой картине мира репрезентируют лексемы давлачев «богач, богатей», давлачевси «богатый», дурхъаси «богатый», арц «деньги», а концепт «бедность» выражает лексема мискин «бедняк; бедный» с производными мискиндеш «бедность», мискинси «бедный». Архисемой лексического значения слова давла «богатство» является «наличие материальных ценностей», а архисемой лексического значения слова мискин «бедный» является отсутствие этих ценностей. Концептосфера «богатство» и «бедность» имеет одно основание, но разные вершины.

Ключевые слова: концепт «богатство», концепт «бедность», концептосфера, пословицы и поговорки, паремии.

«бедность - богатство» в даргинской лингвокультуре на уровне паремических единиц языка.

Научная новизна статьи состоит в том, что результаты данного исследования являются первым опытом изучения этнолингвистических особенностей вербализации антиномии «богатство и бедность» на паремиологическом уровне даргинского языка.

В даргинской языковой картине мира «богатство» как ценность является носителем как положительной, так и отрицательной коннотации. В большинстве своем «богатство» рассматривается в положительном аспекте и означает благо, как материальное, так и духовное. В даргинской языковой картине мира представлены паремии, которые описывают «богатство» как благо народа: ум, доброта, щедрость, дружба и семья намного важнее, чем материальные блага. Однако необходимо отметить, что частотность пословиц и поговорок с положительной коннотацией по данным «Словаря даргинских пословиц и поговорок» У.У. Гасановой [1] значительно меньше по сравнению с отрицательной коннотацией концепта «богатство».

Рассмотрим паремии, описывающие «богатство» как

Целью статьи является описание концептосферы ность» и «богатство» в даргинской лингвокультуре предметом - особенности паремических единиц даргинского языка, которые репрезентируют концепты «бедность» и «богатство». 
благо. Даргинский народ всегда ценил мастерство и талант, что отразилось и в пословичной картине мира даргинцев. В даргинских пословицах и поговорках мастерство и талант рассматриваются выше всяких материальных благ: Устадеш - авадандеш. «Мастерство — это богатство». Давламаслизибадун ах1ендигахъуси, пагьлизибадрасаби. «Богатство не в имуществе, а в таланте».

Искусных мастеров среди даргинцев много, поэтому во многих фольклорных жанрах даргинцев говорится о трудолюбии мастеров. В национальном сознании даргинцев хороший мастер никогда не будет стремиться к материальным благам, богатству: Г1ях1си уста давлачев хlейрар. «Хороший мастер не станет богачом». Г1ях1си устани муэрлизир х1янчи чедиу, давлачевилли - ари. «Хорошему мастеру работа снится, богачу — деньги».

Мудрые даргинские пословицы и поговорки отличаются проницательностью к семейной жизни. Они подчеркивают, что согласие в семье является главным богатством человека: Эгер хъалибарг балбикалли, давла 21яг1ниси ах1ен. «Если в семье лад, богатство не понадобится».

Большое значение придается такому качеству богатства, как сила. С деньгами у человека есть власть, почет и уважение в обществе, что подтверждают следующие пословицы: Давла и1акь саби. «Богатство - сила». Давлали х1ейхъути дубурти х1ейрар. «Богатство пройдет через любые горы». Х1урмат лебу - давла леб, давла лебу - х1урмат леб. «Есть богатство, есть почет, есть почет, есть уважение». Арилис талхъа рурсира асес вирар. «За деньги можно купить даже принцессу». Арили чиналра гьуни кайсу. «Деньги везде находят дорогу». Арилизибад дубурара урухкlар. «Даже гора боится денег». Арилис маллара ц1уц1лантани калхъан. «За деньги даже мулла станцует».

В пословичной картине мира даргинцев богатство рассматривается как временное явление, «оно может появиться внезапно и также быстро исчезнуть» [3, с. 130]: Сверхбогатый человек тоже может потерять свои деньги и стать обычным человеком: Масла давла - amх1ебла дях1и саби. «Богатство, что весенний снег». Давла - дашути ардашути шин сари. «Богатство - вода: как пришла, так и ушла». Мулкла вег1лизиб мурталра мулк ках1евлан. «Богач всегда богатым не будет».

Даргинские пословицы предупреждают, что и богатый и бедный не вечны, и богатство с собой на тот свет не заберешь: Давлачевсира убк1ар, мискинсира убк1ар. «И богатый умирает, и бедный». Сецад давла бучадра, дунбяличиб балтад. «Сколько бы богатства ни собрал, все останется здесь».

Согласно даргинским пословицам и поговоркам, богатство портит человека: Халаси давлали хяличи шурвалта. «Богатство превращает человека в собаку», он становится зависимым от денег и с жадностью смотрит на каждую копейку: Арила хазнализи кайибх1елира, кепеклизивад далдаркавхъи сай. «Живущий в богатстве зависит от копейки». Богатство подчиняет человека, лишает его свободы, накладывает определенные рамки, мешающие совершать те или иные действия. Причем, чем больше богатства, тем больше зависимость от него и подчиненность. Приведем примеры, демонстрирующие, что наличие богатства приводит к отсутствию человечности, ума, счастья, любви, здоровья: Духусилахазна - багьуди, ахмахла хазна - давла. «Богатство умного - знания, богатство глупца - имущество». Арили адам ветх1ерахъу. «Деньги не делают человека».

В языковой картине мира не только даргинцев, но и других народов Дагестана ум и знание ценятся выше богатства: Пякълу давлаличибра дурхъаси саби. «Ум дороже богатства». Бег1ла халаси давла - багьуди. «Знание богатство».

Понятия скупость и жадность выступают в даргинской языковой картине как антиценности и рассматриваются как социальное зло и несчастье. Согласно даргинской пословичной картине мира, такие универсальные социальные качества, как богатство и бедность делают человека или жадным, или щедрым: богатство делает его жадным, а бедность - щедрым. Масли адам кьиркьир виркьу, мискиндешли сахават виркьу. «Богатство делает человека жадным, бедность - щедрым». В даргинском менталитете, чем богаче человек, тем жаднее: Давлачевси иад - кьиркъирси вирар. «Чем богаче, тем жаднее».

Щедрость и жадность как биномные понятия сравниваются с богатством и бедностью: Кьиркьир давлачевсиличив сахаватси мискин гьалав сай. «Щедрый бедняк лучше, чем жадный богач».

Жадность, как отрицательная черта человека, субстанциально присуща богатому человеку. В даргинском менталитете с возрастом человек становится умнее и мудрее, однако богатый даже с возрастом остается жадным: Давлачевси ухънавиуцад кьиркьир вирар. «С возрастом богач становится жаднее».

Богатый человек до такой степени жмот и скряга, что его глаза с жадностью смотрят на имущество бедного: Давлачевла х1улби мискинна масличир дирар. «Глаза богача смотрят на имущество бедняка».

Как видим, данные пословицы иллюстрируют «богатство» в негативном аспекте. Наличие материального блага не только нежелательно, оно портит человека, приводит к скупости, ухудшению межличностных отношений. 
Образы, характеризующие скупого человека в даргинских пословицах и поговорках, довольно разнообразны. В следующей пословице внешнее проявление жадности связано с едой: Кьиркъирла кьумур халаси биpap, кьаul - биштlacu. «У жадного поднос больше, чем еда на подносе».

К жадному человеку редко обращаются с просьбами, понимая, что его социальный статус связан с отсутствием материальных (предметных) ценностей, к нему мало ходят гости. Поэтому даргинская пословица гласит: Кьиркъирла унза-ганзи х1елукан. «У жадного порог не сотрется».

Жадность в даргинских пословицах - зло, которое до добра не доводит: Кьиркьирдешли г1ях1деш хlеху. «Жадность до добра не доводит».

На протяжении существования человечества люди задавали себе вопросы, связанные с тем, можно ли быть честным и богатым или честность связана с бедностью, принесет ли богатство свободу или человек будет зависеть от него.

Лингвокультурологический анализ позволяет говорить о том, что честность выступает одним из основных элементов концепта «богатство», которая дороже материального богатства, например: Мургьи-арцличиб умуси у гьалаб саби. «Честное имя дороже богатства».

Одной из важных ценностей народного опыта является дружба, которая в пословичной картине мира многих народов, в том числе и даргинцев, имеет непосредственное отношение к богатству. Однако в паремийном фонде даргинского языка ценность «дружба» в отношении к богатству проявляет себя двояко. С одной стороны, пословицы с рассматриваемой семантикой утверждают, что при наличии богатства (денег) у человека появляются друзья: Давла имц1абик1уцад, юлдашунира ими1 абирар. «Когда богатеешь, друзья появляются». С другой стороны, богатство находит человеку и врагов: Багьудили гьалмагъуни бургу, давлали - душманти. «Знания дают друзей, богатство - врагов».

В даргинской пословичной картине мира деньги являются самым распространенным средством выражения концепта «богатство». Они в исследуемой лингвокультуре рассматриваются как символ богатства. Отношение к деньгам в обществе претерпевает значительные изменения. Деньги в современной жизни могут быть источником добра, т.е. посредством денег человек может приносить пользу и себе, и обществу, например, оказать материальную помощь бедным.

Даргинские пословицы и поговорки предупреждают о том, что богатству сопутствует горе: Халаси балагьли- зи викес х1ейгадли, халаси давлаличи гъаргъмайруд. «Не хочешь большого горя, не стремись к большому богатству».

В даргинском языке самым большим богатством является здоровье: Арадеш - бег1лара дурхъаси давласаби. «Самое большое богатство - здоровье». Поэтому даргинцы материальное богатство предлагают другим, а здоровье - себе. Давла - урхлис, арадеш - вег1лис. «Богатство - чужим, здоровье - себе».

Пословицы и поговорки, зафиксировавшие отношение даргинского народа к закону - отношение, вобравшее в себя многовековой опыт. Опираясь на даргинские половицы и поговорки, можно сделать вывод о том, что эти паремии выражают позитивное или негативное отношение разных социальных слоев народа к действующему законодательству или его исполнению. Простой народ всегда испытывал негативное отношение к зажиточным людям, которые всегда могли обойти закон с помощью откупа. Арила вег1лис закон лебси ах1ен. «Для богатого нет закона».

В дошедших до нас из глубины веков паремиологических единицах богатство сравнивается с воровством. Это, видимо, обусловлено тем, что исторически кража была первым видом имущественных преступлений: Хъулки давлачев х1ейрар. «Вор не разбогатеет». Хъулкила давла имиl axleбирар. «Богатство у вора не прибавится».

Ряд паремических единиц содержит в себе отрицательное значение богатства. Так, даргинские пословицы говорят о том, что в деньгах не стоит искать братства, дружбы, счастья. Это иллюстрируют следующие пословицы: Талих 1 давлализибиун биэсх 1ебирар. «Не в деньгах счастье». Давлачев узини мискин узи валх1ела. «Богатый брат не знает бедного брата».

Особое внимание обращается в пословицах и поговорках новоявленному богатому: Давлачев виубси мискин адамлизи чеблалис ари тилади мадирид. «У новоявленного богатого не проси денег в долг».

Согласно даргинским пословицам и поговоркам, богатые и бедные думают и мыслят по-разному, они даже говорят на разные темы, и это логично: Масла бег1mu «мас» бик1ар, мискинти - «дурх1ни» бик1ар. «Богатые говорят о богатстве, бедные - о детях».

По мнению А.М. Никатуевой, «некоторые цветообозначения в даргинском языке отражают такое понятие, как «богатство» и его осмысление даргинцами». Для подтверждения своих мыслей автор приводит такие пословицы и поговорки: Мургьи се заманалра мяржх1ебирар. «Золото никогда не ржавеет». Мургьи-арила кьимат мурталра х1ебубк1ар. «Золото всегда в цене». Мургьила 
мякьлаб мегьра лямц1бик1ар. «Рядом с золотом и желе30 блестит» [4, с. 259]. На наш взгляд, нельзя согласиться с мнением автора по следующим соображениям: вопервых, ни в одном из приведенных А.М. Никатуевой примерах нет цветообозначений, во-вторых, ни один из приведенных примеров не выражает значения «богатство». Лексема мургьи «золото» во всех приведенных автором примерах использовано в прямом значении, и в них речь идет о золоте как драгоценном металле.

Исследование показало, что концепт «бедность» репрезентируется словами, восходящими к одной основе (мискин «бедняк; бедный» и производные мискиндеш «бедность», мискинси «бедный»), а концепт «богатство» репрезентируется достаточно большим количеством имен, имеющих как одинаковые (давлачев «богач, богатей», давлачевси «богатый»), так и разные основы (давла «богатство», дурхъаси «богатый», ари «деньги»). Основными именами существительными, репрезентирующими и составляющими имена концептов, являются давла «богатство» и мискиндеш «бедность».

Концептосфера «богатство» и «бедность» в даргин- ском языке имеет «одно основание, но разные вершины. Основным элементом концептов (глубинным представлением о богатстве и бедности) является противопоставление власть - подчинение» [2, с. 17]. Доминанты синонимических рядов составляют имена концептов «богатство» (давла) и «бедность» (мискин). Наличие синонимических рядов говорит о том, что существуют разные лексические способы вербальной репрезентации данных концептов. Ядро концептов составляют лексемы, являющиеся доминантами синонимических рядов, на периферии располагаются их синонимы. Различные оттенки значений синонимических рядов указывают на многогранность и разноплановость концептов.

Материальное и нематериальное восприятие бедности и богатства четко не разделяются, так как материальные и духовные ценности взаимосвязаны между собой. Перспективы данного исследования связаны с сопоставительным изучением концептов «богатство» и «бедность» с другими родственными и неродственными языками, а также изучением концептов в оппозиции с другими концептами, что позволит установить и выявить межконцептуальные отношения.

\section{ЛИТЕРАТУРА}

1. Гасанова У.У. Словарь даргинских пословиц и поговорок. — Махачкала: Дагестанский государственный университет, 2019. — 230 с.

2. Гетман А.А. Концептосфера «бедность - богатство» в англо-американской лингвокультуре: автореф. дис. ...канд. филол. наук. — Новосибирск, 2015. — 24 с.

3. Медведева Т.С. К вопросу о сопоставлении лингвокультурных концептов // Вестник Удмуртск. ун-та. История и филология. - 2009. - № 5-1. - С. 120-132.

4. Никатуева А.М. Цветообозначающая лексика в паремиях даргинского языка // Мир науки, культуры, образования, №4, 2017. — С. 259-260. 